\title{
Native DNA binding in rheumatoid arthritis
}

\author{
PAUL G. ROCHMIS, HOWARD PALEFSKY, MICHAEL BECKER, \\ HENRY ROTH, AND NATHAN J. ZVAIFLER \\ From the Department of Medicine, Georgetown University, School of Medicine, Washington, D.C., and \\ the Department of Medicine, University of California, San Diego School of Medicine
}

With the introduction of the ammonium sulphate precipitation (Farr) technique, a sensitive procedure for the detection of antibodies to either native deoxyribonucleic acid (nDNA) or heat-denatured singlestranded deoxyribonucleic acid (sDNA) has become available (Wold, Young, Tan, and Farr, 1968). Furthermore, quantitation of the amount of antibody present in the test serum can be expressed with greater accuracy and as a continuous variable. Previous studies have shown the value of this method for the detection of anti-DNA antibody (described as DNAbinding) in systemic lupus erythematosus (SLE) and have suggested its use as a definitive test for the diagnosis of, and also for following the course of, disease activity (Hughes, 1971; Hughes, Cohn, and Christian, 1971; Pincus, Schur, Rose, Decker, and Talal, 1969).

On occasions it is difficult to make a clinical distinction between rheumatoid arthritis and SLE. Furthermore, LE cells and antinuclear antibodies are present at times in both diseases. A test to discriminate between them would be useful. However, no systematic analysis had been done to determine the prevalence of antibody to nDNA in a large group of patients with well-characterized rheumatoid arthritis. This has been done in the current study and the results show that antibodies to nDNA are only rarely present in the serum of the patient with rheumatoid arthritis.

\section{Materials and methods}

\section{PATIENT SELECTION}

Sixty-two patients with rheumatoid arthritis who were either hospitalized or being treated as outpatients were studied. A group of local rheumatologists selected these patients on the basis of their having unequivocal rheumatoid arthritis and meeting the A.R.A. criteria for definite or classical disease (Ropes, Bennett, Cobb, Jacox, and Jessar, 1959). The data collected included patient's age, sex, erythrocyte sedimentation rate, an estimation of the number of joints actively involved with arthritis at the time of the examination, and a judgement on the overall severity of the disease process. The presence or absence of extra-articular manifestations of rheumatoid arthritis was also recorded. These included weight loss, nodules, fever, digital arteritis, cardiopulmonary abnormalities, symptoms of Sjögren's syndrome, peripheral neuropathy, or Felty's syndrome.

\section{LABORATORY STUDIES}

\section{DNA-binding assay}

The source of radio-active DNA was a phenol extract of KB cells, a human tumour cell line, grown in the presence of tritium $\left({ }^{3} \mathrm{H}\right)$ labelled thymidine (Electronucleonics, Bethesda, Md.). Serum DNA binding activity was determined by the method of Pincus and others (1969). A Nuclear-Chicago scintillation counter was used to measure the radioactivity. DNA binding was expressed as the per cent. of radioactivity precipitated by $50 \%$ saturated ammonium sulphate. Serum from 30 normal subjects showed less than $10 \%$ binding. ${ }^{*}$

\section{Other laboratory procedures}

Rheumatoid factor was measured by the bentonite flocculation technique (Bloch and Bunim, 1959); serum immunoglobulins (IgG, IgA, and IgM) and the third component of complement (C3) were quantified by radial immunodiffusion employing Hyland plates (Hyland Laboratories, Los Angeles, Calif.). Antinuclear antibodies were detected by an indirect immunofluorescent technique employing mouse kidney cells as the source of nuclei (Zvaifler and Martinez, 1971).

\section{Results}

\section{CLINICAL CHARACTERIZATION}

Sixty-two patients with definite or classical rheumatoid arthritis were studied. $49(80 \%)$ were female and thirteen $(20 \%)$ male. The total average age was 51.8 years, with the average age of the females being 51.3 years and of the males being 53.4 years. Nineteen patients had their disease for 2 years or less, thirteen patients for between 2 to 5 years, nine for 5 to 10 years, and 21 had the disease for more than 10 years. The median duration then fell in the group from 2 to 5 years. Using a semi-quantitative grading

* All assays were performed at least three times; published values represent means, variation on re-run of the assays being between $1-2 \%$ binding. Intra-run error was less than $\pm 3 \%$ of the actual measurement. 
system for the severity of joint involvement, it was found that 24 patients had what was considered to be mild disease activity, 25 had moderate, and ten were characterized as severe. Two patients were in remission, and data were not available for one patient. A recent erythrocyte sedimentation rate (predominantly by the Westergren technique) was available for 51 patients; the mean value was $40 \mathrm{~mm} / \mathrm{hr}$. 38 of the 62 patients had current extra-articular manifestations such as digital arteritis, neuropathy, nodules, Sjögren's syndrome, pulmonary involvement, etc.

\section{SEROLOGICAL STUDIES}

Fifty-four $(85.7 \%)$ of the patients had a positive test for rheumatoid factor-defined as a bentonite flocculation test (BFT) positive in a serum dilution of $1: 32$ or higher. The range of values is shown in Table I. The mean titre was 512. Fluorescent antinuclear antibody (FANA) determinations were posi-

Table I Bentonite flocculation test (BFT) titres: range of values for the 62 patients. Median titre-512

\begin{tabular}{|c|c|}
\hline BFT titre & No. of patients \\
\hline $\begin{array}{l}0-16 \\
32 \\
64 \\
128 \\
256 \\
512 \\
1,024 \text { or greater }\end{array}$ & $\begin{array}{l}9 \\
3 \\
3 \\
4 \\
7 \\
10 \text { (median) } \\
26\end{array}$ \\
\hline
\end{tabular}

tive in twelve of 62 patients $(19 \%)$, with a clear pattern of nuclear fluorescence at a serum dilution of $1: 10$ or higher required for positivity. 61 of the 62 patients had determinations made of IgG, IgA, IgM, and the third component of complement (C3) and the mean values are shown in Table II.

Table II Mean values for determinations of immunoglobulins $G, A$, and $M$, and for the third component of complement (C3). Range of values observed and normal range

\begin{tabular}{|c|c|c|c|}
\hline Test & Mean & Range of values & Normal range \\
\hline $\begin{array}{l}\text { IgG (mg/ml) } \\
\text { IgA (mg/ml) } \\
\text { IgM (mg/ml) } \\
\text { C3 (mg/100 ml) }\end{array}$ & $\begin{array}{c}12 \cdot 2 \\
2 \cdot 2 \\
2 \cdot 3 \\
187\end{array}$ & $\begin{array}{l}5 \cdot 5-24 \cdot 2 \\
0 \cdot 4-5 \cdot 7 \\
0 \cdot 5-18 \cdot 0 \\
82-277\end{array}$ & $\begin{array}{l}7 \cdot 7-11 \cdot 3 \\
0 \cdot 8-2 \cdot 0 \\
0 \cdot 9-1 \cdot 7 \\
125-200\end{array}$ \\
\hline
\end{tabular}

PER CENT. DNA BINDING

Fifty-nine of the 62 patients had DNA binding values between $0-10 \%$. One patient had a value of $13 \%$ and two others had values of $19 \%$ and $23 \%$, respectively. Laboratory data on these three patients is presented in Table III. It is interesting to note that the two
Table III Laboratory data on the three patients with raised \% DNA binding

\begin{tabular}{|c|c|c|c|}
\hline & Case 1 & Case 2 & Case 3 \\
\hline $\begin{array}{l}\text { Per cent. DNA } \\
\text { bound }\end{array}$ & 19 & 23 & 13 \\
\hline $\operatorname{ESR}(\mathrm{mm} / \mathrm{hr})$ & 123 & - & 45 \\
\hline BFT & Negative & Negative & $\geqslant 1: 1024$ \\
\hline FANA & Negative & Negative & Negative \\
\hline $\mathrm{C} 3(\mathrm{mg} / 100 \mathrm{ml})$ & 230 & 182 & 192 \\
\hline $\mathrm{IgG}(\mathrm{mg} / \mathrm{ml})$ & $24 \cdot 2$ & $22 \cdot 3$ & $11 \cdot 7$ \\
\hline $\mathrm{IgA}(\mathrm{mg} / \mathrm{ml})$ & $4 \cdot 3$ & $3 \cdot 4$ & $3 \cdot 1$ \\
\hline $\mathrm{IgM}(\mathrm{mg} / \mathrm{ml})$ & $3 \cdot 0$ & $7 \cdot 2$ & $2 \cdot 6$ \\
\hline
\end{tabular}

patients with the highest per cent. DNA-binding values had negative BFT tests; they are detailed below

Case 1 A 48-year-old woman developed rheumatoid arthritis after her tenth pregnancy in 1964. She was seen for the first time in the Rheumatology Clinic of the District of Columbia General Hospital on April 6, 1970 , because of a recent exacerbation of the arthritis in multiple joints. She had been treated with buffered aspirin, indomethacin, acetaminophen, and corticosteroids in the past. Physical examination revealed active synovitis of the knees, wrists, metacarpophalangeal joints of the hands, and shoulders, in addition to fixed deformities including flexion contractures of the hips and knees and instability at the wrists and metacarpophalangeal joints. Laboratory studies included a Westergren sedimentation rate of $103 \mathrm{~mm} / \mathrm{hr}$ and negative BFT. The patient was hospitalized for treatment with salicylates, low-dose corticosteroids, and intense physical therapy, and upon discharge was able to walk for the first time in about one year. On November 23, 1970, chloroquine $250 \mathrm{mg}$ daily was begun and the arthritis continued under good control, requiring only occasional intraarticular steroid injections. DNA binding was determined to be $19 \%$. FANA was negative.

Case 2 A 40-year-old woman had a 22-year history of rheumatoid arthritis involving the cervical spine, elbows, wrists, metacarpophalangeal and proximal interphalangeal joints of the hands, knees, ankles, and subtalar and metatarsophalangeal joints of the feet. Radiological examination revealed classical erosive and destructive features of rheumatoid arthritis. In the past she had a wide variety of medical therapies and numerous surgical procedures, including synovectomies of both wrists and metatarsal head resections. At the time of the study she was being treated with low-dose prednisone, salicylates, and periodic joint injection with corticosteroids. The Westergren sedimentation rate was $78 \mathrm{~mm} / \mathrm{hr}$, BFT and FANA negative, and DNA binding $23 \%$. 


\section{Discussion}

Wold and others (1968) noted that DNA is soluble in half-saturated ammonium sulphate, whereas DNA bound to $\gamma$-globulin is precipitated. This forms the basis for a sensitive, highly specific assay for DNA antibodies. Employing this technique, a number of workers have shown that the majority of patients with active SLE have serum antibodies to native DNA (Carr, Koffler, Agnello, and Kunkel, 1969; Hughes, 1971; Hughes and others, 1971; Koffler, Carr, Agnello, Thoburn, and Kunkel, 1971; Pincus and others, 1969; Wold and others, 1968). To date, the only other diseases reported to have a significant incidence of antinative DNA antibody have been discoid lupus erythematosus-8 of 22 patients (Mandel, Carr, Weston, Sams, Harbeck, and Krueger, 1972), and Sjögren's syndrome-6 of 24 subjects with increased binding (Pincus and others, 1969). Both disorders have many features in common with SLE. Using a solid phase radioimmunoassay, Epstein, Tan, and Easterbrook (1971) found that the serum of $24 \%$ of patients with idiopathic and secondary uveitis contained antibodies to double-stranded (native) DNA. The meaning of this finding is uncertain at the present time.

Because rheumatoid arthritis and SLE share a number of clinical and serological features, it was considered of interest to examine serum from a large group of typical rheumatoid patients for the presence of DNA binding activity. Their binding was compared with a control group. The serum nDNA binding of thirty normal subjects was found to be less than $10 \%$ (mean +1 standard deviation). Three of the 62 rheumatoid patients showed greater than $10 \%$ binding, but only one exceeded $20 \%$. Hughes (1971) included twenty patients with adult rheumatoid arthritis and 14 with juvenile rheumatoid arthritis as controls in his study of anti-native DNA antibodies in SLE. The highest binding was $11 \%$, observed in a child with rheumatoid arthritis who subsequently developed manifestations of SLE and the diagnosis was changed accordingly (G. R. V. Hughes, personal communication, 1973).

Only one of ten rheumatoid subjects studied by Carr and others (1969) showed more than $10 \%$ binding. Binding of greater than $20 \%$ was found in three of 57 disease controls recorded by Pincus and his coworkers (1969). One of these had rheumatoid arthritis, another, Felty's syndrome. None of the three patients with increased DNA binding in the present study had clinical evidence of Sjögren's or Felty's syndrome, though more than half of the entire group had extra-articular manifestations of rheumatoid arthritis. The serum of approximately $20 \%$ of the rheumatoid patients had antinuclear antibody, but there was no correlation with DNA binding activity. Thus, the demonstration of significant amounts of antibody to native DNA in patients with arthritis and positive antinuclear antibody tests would strongly favor the diagnosis of SLE.

Antibodies to denatured (single stranded) DNA do not have the same specificity as antibodies to nDNA, since they are found in a variety of diseases where evidence of tissue injury exists. In one series more than $50 \%$ of rheumatoid arthritis patients had serum antibodies to ssDNA (Koffler and others, 1971). To exclude the possibility that the increased binding observed in this study was due to contamination of the nDNA by denatured DNA, the radiolabelled DNA was subjected to cesium gradient analysis. More than $96 \%$ of the radioactivity was associated with native DNA. Thus, the 19 and $23 \%$ binding observed in two of the rheumatoid patients cannot be explained by binding to denatured DNA. Evidence that the binding reactant is actually immunoglobulin has been presented by Wold and others (1968). Heat inactivation does not block the binding, but does destroy the binding activity of $\mathrm{Clq}$, the other known reactant with DNA.

The significance of a negative rheumatoid factor test in the two patients with the highest levels of DNA binding is unclear. They did not seem to differ significantly in terms of their clinical or laboratory parameters from the others in the group. It will, however, be interesting to determine whether a small subgroup of rheumatoid patients exists with significant DNA binding and negative rheumatoid factors, and whether their clinical presentation or course of disease activity is different.

\section{Summary}

Detection of anti-DNA antibodies using the ammonium sulphate precipitation technique has been studied in systemic lupus erythematosus and found to be of value. Data are presented on the prevalence of antinative DNA antibodies in a group of 62 wellcharacterized patients with rheumatoid arthritis. 59 of the 62 patients had negative values (binding less than $10 \%$ ), and the other three patients had binding capacities of 13,19 , and $23 \%$. Interestingly, the latter two patients had negative rheumatoid factor tests, whereas $86 \%$ of the entire group was positive. These data suggest that antibodies to native deoxyribonucleic acid are only rarely present in the serum of the patient with rheumatoid arthritis.

The authors wish to thank Drs. Howard Levine, Charles Brandt, Joseph Croft, and Thomas Pekin, who contributed patients to this study. We are grateful to Dr. John Decker who provided the original radiolabelled DNA and control serum used to standardize the procedure. Excellent technical assistance was provided by Maria Cullen and Stuart Hesketh. Ms. Deborah Ann Frank typed the manuscript. 


\section{References}

Bloch, K. J., AND Bunim, J. J. (1959) J. Amer. med. Ass., 169, 307 (Simple rapid diagnostic test for rheumatoid arthritis-bentonite flocculation test)

Carr, R. I., Koffler, D., Agnello, V., And Kunkel, H. G. (1969) Clin. exp. Immunol., 4, 527 (Studies on DNA antibody using DNA labelled with actinomycin D $\left(\mathrm{H}^{\prime} 3\right)$ sulfate or dimethyl $\left(\mathrm{H}^{\prime} 3\right)$ sulfate)

Epstein, W. V., Tan, M., and Easterbrook, M. (1971) New Engl. J. Med., 285, 1502 (Serum antibody to doublestranded RNA and DNA in patients with idiopathic and secondary uveitis)

Hughes, G. R. V. (1971) Lancet, 2, 861 (Significance of anti-DNA antibodies in systemic lupus erythematosus)

- Cohn, S. A., And Christian, C. L. (1971) Ann. rheum. Dis., 30, 259 (Anti-DNA activity in systemic lupus erythematosus)

Koffler, D., Carr, R., Agnello, V.. Thoburn, R., and Kunkel, H. G. (1971) J. exp. Med., 134, 294 (Antibodies to polynucleotides in human sera: antigenic specificity and relation to disease)

Mandel, M. J., Carr, R. I., Weston, W. L., Sams, W. M., Harbeck, R. J., and Krueger, G. C. (1972) Arch. Derm., 106, 668 (Anti-native DNA antibodies in discoid lupus erythematosus)

Pincus, T., Schur, P. H., Rose, J. A., Decker, J. L., And Talal, N. (1969) New Engl. J. Med., 281, 701 (Measurement of serum DNA-binding activity in systemic lupus erythematosus)

Ropes, M. W., Bennett, G. A., Cobb, S. J., Jacox, R., And Jessar, R. A. (1959) Ann. rheum. Dis., 18, 49 (Diagnostic criteria for rheumatoid arthritis. 1958 revision)

Wold, R. T., Young, F. E., Tan, E. M., AND FarR, R. S. (1968) Science, 161, 806 (Deoxyribonucleic acid antibody: a method to detect its primary interaction with deoxyribonucleic acid)

Zvaifler, N. J., AND Martinez, M. M. (1971) Clin. exp. Immunol., 8, 271 (Antinuclear factors and chronic articular inflammation) 